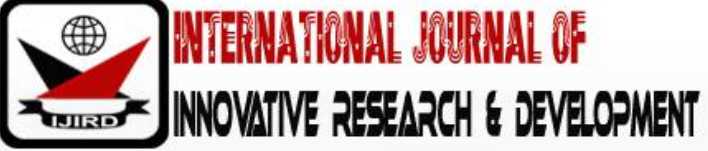

ISSN 2278 - 0211 (Online)

\section{National Sports Policy Implementation and Nigeria’s Foreign Policy}

\author{
Gbeke Adebowale Adenuga \\ Doctoral Student, Department of Political Science and Public Administration, Babcock University, Nigeria \\ Dr. Jones O. Aluko \\ Professor, Department of Political Science and Public Administration, Babcock University, Nigeria \\ Dr. Ngozi Nwogwugwu \\ Senior Lecturer, Department of Political Science and Public Administration, Babcock University, Nigeria
}

\begin{abstract}
:
The review of Nigeria's foreign policy objectives, as conducted by the Yar 'Adua administration, made the articulation of a better image for the country a core foreign policy objective. The Yar 'Adua administration also formulated the 2009 National Sports Policy with a key objective of using Nigeria's performances in as well as the hosting international sporting events, especially the Olympic Games and the Federation Internationale de Football Association (FIFA) World Cup Finals, as a strategy to achieve the aspiration of promoting her image in the international community. However, since the formulation of the 2009 National Sports Policy, Nigeria's performances in these events have not been impressive enough to ensure the promotion of her image in the international community. The study therefore evaluated the implementation of the 2009 National Sports Policy and the challenges of using sports to promote Nigeria's foreign policy. The study found that the implementation of the Policy was limited by the low level of its awareness which hindered the promotion of Nigeria's foreign policy. The study therefore recommended periodic joint monitoring of the implementation of the Policy by relevant stakeholders to ensure the utilisation of the sports policy in promoting Nigeria's foreign policy.
\end{abstract}

Keywords: FIFA world cup, foreign policy, international sports events, national sports policy, Olympic Games

\section{Introduction}

At independence, Nigeria's foreign policy objectives were many and lofty. They included but were not limited to the protection of the sovereign and territorial integrity of the Nigerian state; the promotion of the economic and social well-being of Nigerians; the enhancement of Nigeria's image and status in the World at large; and the promotion of the unity as well as the total political, economic, social and cultural liberation of Nigeria and Africa. However, the Umaru Yar'Adua Administration undertook a successful review of these foreign policy objectives and came up with a set of foreign policy objectives which included the need to articulate a better image for Nigeria and improve the country's relationship with the outside world by cultivating goodwill for Nigeria; seek closer and better relations with the major and emerging powers; facilitate rapid and sustained economic growth and development; amongst others.

Central to this study is the specific objective hinging on the articulation of a better image for Nigeria and improving the country's relationship with the outside world by cultivating goodwill for Nigeria. This is an admission that Nigeria has an image deficit in the international system which, coupled with inadequate goodwill, makes it difficult for her to achieve other foreign policy objectives. It is in view of this need to launder the image of the Nigerian State that the Yar'Adua administration in 2009 formulated a National Sports Policy which has as core objectives the usage of the achievements in sports to boost the country's image in the international system and the attraction of major international sporting events to Nigeria and exploit their benefits for tourism and the economy.

However, as lofty as the ideals of the 2009 National Sports Policy are, it has not achieved the desired objectives, given the fact that it has not translated into impressive performances of Nigeria's sport teams in major international sports competitions, especially the Olympic Games and the Senior Male FIFA World Cup Finals, and neither has it facilitated the hosting of any of these two most important international sporting events by Nigeria since the Policy was formulated. Consequently, this study seeks to examine the challenges responsible for the dismal performances of Nigeria in these international sports competitions and her inability to successfully bid for the hosting of these international sporting events, thereby limiting the effectiveness of the 2009 National Sports Policy to promote Nigeria's foreign policy. 


\subsection{A Critical Analysis of the Strategies of Foreign Policy in Nigeria since Independence}

According to Ade-Ibijola (2013:566), at independence, Nigeria's foreign policy objectives and principles included:

The protection of the sovereign and territorial integrity of the Nigerian state; the promotion of economic and social well-being of Nigerians; the enhancement of Nigeria's image and status in the World at large; the promotion of unity as well as the total political, economic, social and cultural liberation of our country and Africa; the promotion of the rights of the black people and others under colonial domination; the promotion of international cooperation, conducive to the consolidation of world peace and security; promoting mutual respect and friendship among all peoples among the state; redressing the imbalance in the international power structures that has tended to frustrate the legitimate aspirations of developing countries; and the promotion of world peace based on the principles of freedom, mutual respect and equality of all persons of the world.

A critical analysis of the above objectives will reveal that the first four objectives listed above can be regarded as the primary and permanent objectives of Nigeria's foreign policy while the others are secondary objectives which may vary with changes in government. The four objectives are non-negotiable and it is the duty of every government to do everything in its power to protect and promote them. Every policy of successive Nigerian governments must be channelled towards the protection of the sovereignty of the Nigerian State and the preservation of her territorial integrity. It is a noncontestable fact that the promotion of the welfare of its citizenry is a major, if not the major, assignments of every government and in this wise, the promotion of the economic and social well-being of Nigerians should form a major premise for the interaction of Nigeria with other states. Every individual and by extension, every state desires to be accorded a status of prestige and Nigeria is not an exception and finally, Africa as the centrepiece of Nigeria's foreign policy has been a major and constant objective since her independence in 1960.

The notion that these four core objectives are interrelated and the belief that the attainment of these objectives is not mutually exclusive have made successive Nigerian governments to, more often than enough, employ the same set of strategies to achieve these objectives. An analysis of the foreign policy actions of successive Nigerian governments will reveal the general notion that if their policies are targeted towards making Nigeria the acclaimed champion of the African continent, the sovereignty of Nigeria would be guaranteed, her security will be assured through the principle of good neighbourliness and that the attendant prestige that accompanies a continental champion will translate into welfare benefits for her citizenry. To this end therefore, right from the first republic to this present fourth republic, Nigeria has invested heavily into the African continent. Nigeria played leading roles in the formation of the Organisation of African Unity (OAU), the African Union (AU), the African Development Bank (ADB), the New Partnership for African Development (NEPAD) and the African Peer Review Mechanism (APRM) (Wogu, Sholarin \& Chidozie, 2015). She was also in the forefront of the anti-colonialism movement that helped many African States including Angola, Namibia, Mozambique, Zimbabwe, and South Africa to throw off the heavy yoke of external and internal colonialism (Wogu, et al., 2015). It was however in the area of peacekeeping in conflict areas all over the world, especially in the African continent, that Nigeria towers head and shoulder above all other African States. As Ade-Ibijola (2013) notes, Nigeria is ranked fourth in the list of participants in UN peacekeeping missions all over the world. In the African continent, Nigeria has helped to resolve crisis and restore peace and order to crisis ridden States including Congo, Guinea Bissau, Chad, Ivory Coast, Liberia, Sierra Leone, Mali and Sudan (Ashaver, 2014; Lawal \& Aluko, 2016).

Ade-Ibijola (2013), Ashaver (2014), and Lawal and Aluko (2016) also show other roles Nigeria played in making Africa safer and stronger to include the donation of \#13.5m to Angola in 1975; the donation of $\$ 2 \mathrm{~m}$ to South Africa's African National Congress (ANC) in 1976; the donation of $\$ 500,000$ to Namibia's South West Africa People's Organization (SWAPO) in 1976; the donation of $\$ 20 \mathrm{~m}$ to the Zimbabwean liberation movement in 1977; the establishment of a $\$ 800 \mathrm{~m}$ Nigeria Trust Fund under the African Development Bank (ADB) to help African states execute vital projects; the funding of the $\$ 90$ billion peacekeeping mission in Chad in the 1980s; the funding of the over $\$ 12$ billion peacekeeping missions in Liberia and Sierra Leone in the 1990s; over $\$ 82$ million spent on the peacekeeping mission in Sudan in the early 2000s; over \$34 million spent on helping Mali quell the Tuareg rebellion in 2012; and the shouldering of over $60 \%$ of ECOWAS financial responsibility.

However, despite the huge investment Nigeria has committed into the African continent, especially in the areas of setting up continental and regional institutions to facilitate the rapid development of the continent and also in peacekeeping missions, she is yet to truly derive any commensurate dividends from these huge investments that can help her promote her core national interests. The sovereignty and territorial integrity of the Nigerian state is constantly under threat from internal secessionist movements who have sympathisers and financiers outside the country. Nigeria is still considered one of the poorest states in the world (Ade-Ibijola, 2013). Nigeria has an image deficit all over the world (Chidozie, Ibietan \& Ujara, 2014) and her leadership status in Africa remains a subject of debate as some other African countries including Egypt and South Africa also lay claim to the status of the leader of the African continent (Adenuga \& Hassan, 2011). Even many of the countries Nigeria has invested in heavily at her own detriments continually treat her with disdain. Angola, Namibia, Zimbabwe that Nigeria heavily financed in their bids for independence from internal and external colonialism show her utter disregard and it is on record that in 2009 when Nigeria was bidding for a nonpermanent seat on the UN's Security Council, Liberia and Sierra Leone, where many Nigerians died and where billions of naira were spent all in a bid to ensure that peace and security obtained for their citizens, refused to support Nigeria (Lamido, 2012; Lawal \& Aluko, 2016).

It has thus become very necessary to sit back and reconsider our foreign policy objectives and the strategies being employed to achieve these objectives. As Lawal and Aluko (2016: 710) succinctly put it "We should ask ourselves some hard questions: to what extents has our foreign policy benefited Nigerians? To what extent has our foreign policy put food on our tables?" It is the stand of this study that while the foreign policy objectives of Nigeria are indeed very lofty and 
laudable, there is the need to diversify her strategies of achieving these objectives. It is not a problem that Nigeria plays a pivotal role in setting up regulatory institutions in Africa or that she helps in resolving crisis all over the continent but it becomes a problem when she engages in what Sanubi (2012: 281) describes as "megalomaniac spending" of the resources of the state in making other African states comfortable and secure while her own citizens wallow in abject poverty and are daily faced with the problems of insecurity. This study however presents sports as a very good alternative vehicle for achieving Nigeria's foreign policy objectives. As shown from several experiences all over the world, the high media coverage that accompanies sporting activities can be harnessed to optimally promote Nigeria's foreign policy objectives.

\subsection{Nigeria's Performance in the Olympic Games and the FIFA World Cup Finals}

Sports have played some major roles in enhancing the prestige and power status of Nigeria in the international system and in helping with the process of nation building, national integration and unity in the Nigerian state. This study examines the impact of sports on Nigeria from her membership and participation in the two most global sport organisations and their main competitions. These are the International Olympics Committee (IOC) which organises the Olympic Games and the Federation Internationale de Football Association (FIFA) which organises the men football World Cup.

The very first Olympic Games Nigeria participated in as a sovereign State was the 1964 Tokyo Olympics. At that Olympic Games, a young Nigerian, Nojim Maiyegun, helped to lift Nigeria's status in the international system when he won a bronze medal in the boxing event of the Games. This feat beamed global attention on Nigeria as a potential powerhouse in the comity of sporting states and it helped to shore up her status as a sovereign state (Akinboye \& Basiru, 2014). Though Nigeria did not win any medal at the 1968 Mexico City Olympics, her participation was a major boost to her bid to maintain her indivisibility as she was being ravaged by a Civil War which was a serious threat to her sovereignty and territorial integrity. At the 1972 Munich Olympic Games, Nigeria was on the medals' list at the Olympics as another young Nigerian, Isaac Ikhuoria also won a bronze medal in the boxing event. This achievement not only enhanced Nigeria's standing in the international system, it also served as a major healing balm for the Nigerian State after three harrowing years of Civil War as all Nigerians, irrespective of their ethnic or regional affiliations, felt a sense of pride in the achievement. (Adesina, 2016, Ngobua, 2016; Shaagee, 2016).

Based on these feats which heralded her as the African champion in the international sports community, Nigeria was able to organise other African states to boycott the 1976 Montreal Olympic Games to pressurise the international community into making South Africa a pariah State until she stopped her obnoxious racial discriminatory policy of apartheid rule which made black Africans second class citizens in their own State (Ndlovu, 2010). It is instructive to note that the 1976 Olympics did not experience the successes that attended proceeding and succeeding Olympics (Grix, 2014; Nauright, 2013) and this may be attributed to the Nigerian led boycott of the Games. It is also instructive to note that this boycott marked a watershed in the fight against colonialism and racial discriminations in the African continent and it also greatly promoted the core foreign objectives of the Nigerian State. In the first instance, Nigeria's prestige as a major actor on the stages of international sports and politics received a big boost. Secondly, it confirmed Nigeria's status as the regional power in the African continent and thirdly, it also boosted Nigeria's claim as the champion of all people of African descent as her actions sent a strong message that she would not sit idly by when any African is being subjected to discriminatory treatment. All these were achieved through sports despite the fact that the Nigerian State was under military rule.

At the 1980 Moscow Olympic Games, Nigeria did not win any medal but her participation was a major foreign policy statement. The United States of America, with her allies, boycotted the Olympics to protest against the Soviet Union's invasion of Afghanistan (Cohen, 2015; Deos, 2014). Nigeria's participation was thus an indication that she was not tied to the apron string of the United States and her European allies. In the same vein, Nigeria's resolve to be independent of both the United States led Western Bloc and the Soviet Union led Eastern Bloc was also confirmed by her participation in the 1984 Olympics hosted by the American city of Los Angeles. In a reprisal action, the Soviet Union also boycotted the 1984 Olympics (Deos, 2014). Nigeria's participation was thus a clear policy statement of non-alignment. Nigeria also confirmed her status as a sporting state at the 1984 Los Angeles Olympics. Peter Konyegwachie bettered the records of both Maiyegun and Ikhuoria by winning a silver medal in the boxing event. The Nigeria's male 4 x 400 metres relay team also held the whole world spellbound by winning a bronze medal. However, Nigeria could not win any medal at the Seoul Olympics of 1988. Nigeria increased her medal haul and by extension her international prestige at the 1992 Barcelona Olympic Games. The duo of David Izonritei and Richard Igbinebu won silver each in the boxing ring. The male $4 \mathrm{x} 100$ metres relay team bettered their 1984 record by winning silver while their female compatriots won a bronze medal (Adesina, 2016, Ngobua, 2016 \& Shaagee, 2016).

It was however at the 1996 Atlanta Olympics that Nigeria took a giant leap into sporting stardom. Chioma Ajunwa won a gold medal in the women's long jump and the football team tagged "the Dream Team" also won gold in football. The female 400 x 400 metres relay team won a silver medal while Mary Onyali and Falilat Ogunkoya won a bronze medal each in the 200 and 400 metres races respectively. Duncan Dokiwari also got a bronze medal in boxing at the event (Jeroh, 2012a). This achievement, aside from boosting the image of Nigeria globally, also helped to reduce internal political tensions within the Nigerian state in the wake of the annulment of the results of the 1993 presidential elections allegedly won by MKO Abiola, the presidential candidate of the Social Democratic Party (SDP) and the subsequent arrest of Abiola by the Abacha military regime in 1994 when Abiola tried to recover the mandate allegedly given to him by Nigerians at the 1993 presidential elections. These actions generated civil unrest within the Nigerian State and the sterling performance of the Nigerian contingent at 1996 Olympics was a major boost for the maintenance of law and order within the Nigerian 
state as the 'feel good factor' and the pride that accompany the success of one's national sports teams in international events made Nigerians to hope in a better tomorrow for the Nigerian state.

In the 2000 Sydney Olympic Games, Nigeria won gold in the 400 x 100 metres men relay event while Gloria Alozie and Ruth Ogbeifo won a silver medal each in the 100 metres race and weightlifting events respectively. In the 2004 Olympic Games hosted by Athens, Nigeria picked up two bronze medals courtesy of the 400 x 100 and 400 x 400 metres male relay teams. In the 2008 edition of the Games hosted by Beijing, the male football team, the female $400 \times 100$ relay team and Blessing Okagbare in the women long jump won a silver medal each. Chika Chukwumerije in Taekwondo and Mariam Usman in weightlifting also won a bronze medal each. At the 2012 London Olympics, Nigeria was unable to win any medal while it only succeeded in winning just one bronze medal in the football event at the 2016 Olympic Games hosted by the Brazilian city of Rio de Janeiro. A cursory glance at the above will reveal dwindling fortunes for Nigeria at the Olympic Games after her sterling performance at the 1996 edition of the Games with negative effects on her international prestige and status (Adesina, 2016, Ngobua, 2016; Shaagee, 2016).

Though Nigeria did not play in the senior male competition of the Federation Internationale de Football Association (FIFA) popularly referred to as the World Cup Finals until 1994, she was a force to be reckoned with in the organisation. In the first instance, she was a continental champion having won the African Nations cup in 1980 and in 1994. She was also a frontline participant in the FIFA junior World Cup Finals, including the Under-17 and the Under-20 categories, which she had won on many occasions. On the strength of her very impressive credentials, on and off the football pitch, she was able, in 1974, to organise the African votes to remove the incumbent President of FIFA, Stanley Rous, a native of England and to install Joao Havelange, a Brazilian (Ndlovu, 2010). This singular action had tremendous impact on the promotion of Nigeria's foreign policy objectives. Firstly, it established her pedigree as having great influence in the African continent which served to boost her prestige and status in the international system. Secondly, this action was a giant stride in the achievement of her objective to totally eradicate colonialism and racial discrimination in the African continent as Havelange had promised to bar States with such policies from participating in FIFA organised competitions.

In 1994, fresh from her conquest of the African continent, the Nigerian senior football team, the Super Eagles, participated for the very first time in the senior World Cup Finals held in the United States of America. The Nigerian team proved all bookmakers wrong as it qualified for the second round of the competition with apparent ease from her group which had notable football teams including the Bulgarian, Argentine and Greek national football teams. She narrowly lost to Italy, the eventual winner of the competition, in the round of 16 . However, the display of football artistry by members of the team launched Nigeria into global reckoning as a powerhouse in international football and it greatly boosted her prestige and status in the international sport system (Aiyejina, 2016; Akinola, 2014). After the World Cup event, she received many invitations from notable States in the international system, including England, to play friendly football games with their national teams, a very good indication of her heightened prestige in the international system. It should be noted that in 1994, Nigeria was under a military regime led by Gen. Sanni Abacha, which had sacked the Interim Government hastily constituted by the Babangida regime on the eve of its forced ouster from office in 1993 as a result of the backlash that met the annulment of the 1993 presidential elections. The Sanni Abacha regime had also arrested and placed MKO Abiola, who allegedly won the 1993 presidential elections, under house arrest. This act, coupled with other dictatorial policies of Abacha, had made Nigeria unpopular in the international system. Thus, the feat of the Super Eagles in the 1994 World Cup was the more notable because it helped to open avenues of positive interaction between Nigeria and other members of the international system. In the same vein, the sterling performance of the Super Eagles also helped to douse political tensions within the Nigerian State as the mass civil unrest that greeted the actions of the Abacha regime with the arrest of Abiola lost steam as Nigerians, with the exhilaration of the accrued prestige from the performance of the Super Eagles, renewed their hopes for a better and stronger Nigerian State.

In the 1998 World Cup hosted by France, Nigeria also brushed aside the likes of Bulgaria and Spain, two powerhouses in the field of international football, to progress to the Round of 16. She, however, lost woefully to Denmark to exit from the competition. At the 2002 edition of the World Cup co-hosted by Japan and South Korea, Nigeria could not progress out of the group stages. She could not even qualify for the Germany 2006 World Cup and at the 2010, 2014 and 2018 World Cups hosted by South Africa, Brazil and Russia respectively, Nigeria failed to progress out of the group stages (Aiyejina, 2016; Akinola, 2014; Ameh, 2018; Okpara, 2018). Thus, Nigeria has recorded dwindling fortunes in using her membership of FIFA and her participation in the World Cups to boost her foreign policies.

\subsection{The Challenges of the 2009 National Sports Policy}

As stated earlier, the Yar 'Adua administration (2007-2010) reviewed Nigeria's foreign policy and came up with a new set of objectives of which the central objective is the articulation of a better image for the Nigerian State and leveraging on the image to access political and economic benefits in the international community (Aluko, Nwogwugwu \& Adenuga, 2018). Most of the problems bedevilling the 2009 National Sports Policy and by extension, the sports sector in Nigeria revolve around the challenges of inadequate funding and mismanagement. Yazid (2014) posits that the Nigerian sports sector is not adequately funded because there is no public-private partnership to channel needed funds into the sector. All over the world, especially the European States, the United States of America, most of the South American States, China, Japan and South Africa, private individuals and organisations partner with the governments to inject funds into the sports sectors which go a long way to help in providing needed infrastructure, training needs and motivate athletes and their trainers to continually give their best and win laurels for their countries. The reverse is the case in the Nigerian State as around $90 \%$ of the funding that accrues to the sports sector is always from the government (Nwankwo \& Ekechukwu, 2017; Okediji, 2015). 
However, inadequacy of funds seems to be the lesser of two evils when it is compared with the challenge of mismanagement. As Okediji (2015:194) observes, the sports sector in Nigeria is characterised by "embezzlement, misappropriation of fund, wasteful expenses and misrepresentation". Thus, even the inadequate funds that government makes available to the sports end up being mismanaged with the attendant negative effects on the athletes, other sports personnel, sports infrastructure and the entire sports sector. Ajom (2017) put the problem in better perspective when he avers that "most often, when funds are made available, officials siphon the money, leaving the athletes underfed, underpaid and under motivated". The mismanagement of funds also has dire consequences on sports infrastructural development as funds meant to develop the existing infrastructure and procure new ones often end up in private pockets. Thus, most of the sports infrastructure in Nigeria have either become derelict or are in deplorable conditions (Ajom, 2017). The deplorable state of the infrastructure makes the training of athletes an onerous task and this may largely account for the dismal performances of Nigerian athletes in international sporting competitions. Dumo (2017) subscribed to this view after he did the evaluation of Nigeria's performances at the 2016 Brazil Olympic Games. There are some sports which used to be Nigeria's areas of 'specialisation' when it comes to international sporting competition. Boxing is one of such sports as it was the sport that first earned Nigeria her first Olympic medal in 1964 and in which Nigeria had also excelled in the 1972, 1984 and 1996 Olympic Games. However, at the 2016 Brazil Olympic Games, it was disheartening to see that Nigeria was represented by just one boxer, Efe Ajagba, who did valiantly but could not get any medal at the end of the day. The dwindling fortunes of boxing in Nigeria have been ascribed to the deplorable state of boxing infrastructure. Dumo (2017) also noted that weightlifting is also a sport in which Nigeria had bagged many Olympic laurels, even more than the ones boxing gave to the country. However, just like it obtained for boxing, at the 2016 Brazil Olympic Games, Nigeria was represented by just one weightlifter, Oluwatoyin Adesanmi, who also left the Games without any medal. The deplorable state of weightlifting infrastructure in Nigeria was also given as the major causal factor.

Another major manifestation of mismanagement in Nigeria's sport sector is that most of the sports administrators lack any specialised training in sports administration. Yazid (2014) states emphatically that about 83\% of Nigerian sports administrators do not possess sports administration training. This high percentage of administrators without the required sports cognitive abilities can only spell doom for the sports sector as they will not know where the shoe pinches. While it may be argued that most sports administrators are passionate about the sports they oversee, the argument is self-defeatist as passion without knowledge is highly destructive. This phenomenon may be largely responsible for the inability of sports administrators to scout for talents in the making, who will be adequately groomed to fly the flag of the Nigerian State high in international sporting competitions. What obtains today is the overly-concentration of focus and attention on already made talents who, when they eventually burn out or when the law of diminishing returns sets in, they have no successors to hand the batons over to as efforts were not made to train new talents.

Another manifestation of mismanagement in Nigeria's sports sector is also seen in the unwholesome culture of flawed policy formulation processes, policy discontinuities and policy summersaults. For example, Aibueku \& Ogbouma (2013) that major stakeholders were not involved in the formulation processes of both the 1989 and 2009 National Sports Policy which made the implementation of the policies very difficult enterprises. It has also been established that succeeding administrations often discontinue or abandon the policies made by their predecessors. A good example is located in the 2009 National Sports Policy. It was made under the administration of the Late President Umaru Yar'Adua and the succeeding administrations have not bothered to implement it. Ajom (2017) reports that as a result of the dismal performances of the Nigerian sports teams to the 2012 London Olympic Games, former President Jonathan Goodluck held a one-day retreat in the twilight of his administration to ponder on the various challenges besetting the sports sector and to work out modalities to ensure that Nigeria does not perform woefully at subsequent international sporting events. In the first instance, if the Jonathan Goodluck administration had kept faith with the 2009 National Sports Policy, there would have been no need for the retreat. However, it is instructive that the Buhari administration, which succeeded the Jonathan Goodluck administration, did not bother, either to implement the 2009 National Sports Policy or to publish and implement the decisions of the retreat conducted by the preceding administration.

\section{Theoretical Framew ork}

\subsection{National Interest Theory}

The national interest theory, popularised by Hans Morgenthau in his internationally widely acclaimed treatise 'Politics Among Nations: The Struggle for Power and Peace' published in 1948 and which received further clarifications in his other works including 'The Primacy of the National Interest' (1949) and 'In Defense of the National Interest' (1951) has it as its main premise that states engage in foreign relations in order to protect and promote some objectives which are fundamental to the security of the states and to the welfare of their citizens. These objectives are referred to as national interests (Ajayi, Njoaguani, Olorunyomi \& Folarin, 2015). Thus Daniel (2014:6) succinctly defines national interests as "anything which a state considers to be valuable to it". Marleku (2013:416) also defines it as "the perceived needs and desires of one sovereign state in relation to other sovereign states comprising the external environment. From the foregoing, the national interest theory is a theory which argues that states engage in foreign relations in order to protect and promote some certain objectives called national interests which are essential for the protection and promotion of the welfare of their citizens.

However, there are some observable flaws in the national interest theory. As Pham (2008) affirms, a fundamental premise of the theory is that states only expend their resources on activities that will give them real advantages in the international system. The theory also expects governments and not public opinion to determine foreign policy objectives. Firstly, it is fallacious to think that all the states in the international system are guided by the principle of rationality in 
setting foreign policy objectives and that through these objectives, they gain real advantages in the international system. This study has shown that Nigeria has spent a lot of resources on the usage of some foreign policy strategies including peace keeping missions within and outside the African continent and on playing the big brother role in Africa without achieving substantial advantages. Secondly, the inherent danger in subordinating public opinion to governments in the determination of foreign policy objectives is that the interests of the people in government become the national interests and this may lead to policy discontinuities as each succeeding government turn their interests into the national interests.

Despite the weaknesses mentioned above, this study adopts this theory because it provides a broad framework for analysing the reasons underlying the foreign policies of states. A study of Nigeria's old and new foreign policy objectives will reveal that they can all be summarized into the need to ensure the protection and preservation of Nigeria's autonomy as a sovereign state, the security of her citizens from internal and external dangers, the promotion of the welfare of her citizens and the enhancement of her prestige as the giant of the African continent and a force to be reckoned with in the international system. Nigeria has used various foreign policy instruments, notably among which is the participation in international peacekeeping missions in order to promote her national interests. However, these instruments have not optimally yielded the desired dividends for the Nigerian state. Insecurity still prevails in the state; the economy wobbles from one crisis into another with the cost of living taking astronomical leaps while the standard of living daily slides down an abyss with negative implications for the welfare of the Nigerian citizenry. Since the 1980s, Nigeria has consistently suffered an image deficit in the international system. This study, however, presents sports as the veritable instrument for the achievement of the Nigerian national interests. For Daniel (2014) and Pham (2008), every activity of a state in the international system is geared towards the acquisition of power and to use such powers to protect and promote its national interests when interacting with other members of the international system. Thus, the national interests of Nigeria can be better protected and promoted if sports are given a place of pride in the formulation and implementation of Nigeria's foreign policy.

\section{Methodology}

The study adopted the survey research design and the population comprised the 2,570 staff of the Sports wing of the Federal Ministry of Youth and Sports (FMYS); 2,500 staff of the Federal Ministry of Foreign Affairs (FMFA); 120 staff of the Nigerian Institute of International Affairs (NIIA) and 145 staff and 117 registered students of the National Institute for Sports in Nigeria (NIS) for the 2017/ 2018 Academic Session with a total population of 5382. The Taro Yamane formula was used to determine the sample size of 400 while stratified random sampling was used to select the respondents. A validated questionnaire was the instrument for collecting quantitative data. The questionnaire was administered on 189 respondents from the Federal Ministry of Youth and Sports (FMYS); 183 respondents from the Federal Ministry of Foreign Affairs (FMFA); 8 respondents from NIIA and 20 respondents from NIS.

\begin{tabular}{|c|c|c|c|c|c|c|}
\hline & 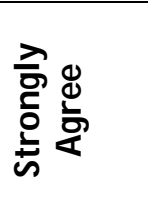 & $\frac{8}{8}$ & $\begin{array}{l}8 \\
\frac{8}{8} \\
\frac{8}{6}\end{array}$ & 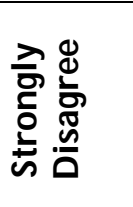 & 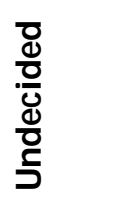 & 疍 \\
\hline $\begin{array}{c}\text { Low awareness about the } \\
2009 \text { National Sports Policy. }\end{array}$ & $\begin{array}{c}291 \\
72.8 \%\end{array}$ & $\begin{array}{c}109 \\
27.3 \%\end{array}$ & $\begin{array}{c}0 \\
0.0 \%\end{array}$ & $\begin{array}{c}0 \\
0.0 \%\end{array}$ & $\begin{array}{c}0 \\
0.0 \%\end{array}$ & 4.73 \\
\hline $\begin{array}{l}\text { Disconnect between the } \\
\text { Ministry of Youth and Sports, } \\
\text { the Ministry of Foreign Policy } \\
\text { and sports and foreign policy } \\
\text { research institutions. }\end{array}$ & $\begin{array}{c}323 \\
80.8 \%\end{array}$ & $\begin{array}{c}77 \\
19.3 \%\end{array}$ & $\begin{array}{c}0 \\
0.0 \%\end{array}$ & $\begin{array}{c}0 \\
0.0 \%\end{array}$ & $\begin{array}{c}0 \\
0.0 \%\end{array}$ & 4.81 \\
\hline Inadequate funding & $\begin{array}{c}318 \\
79.5 \% \\
\end{array}$ & $\begin{array}{c}82 \\
20.5 \% \\
\end{array}$ & $\begin{array}{c}0 \\
0.0 \% \\
\end{array}$ & $\begin{array}{c}0 \\
0.0 \% \\
\end{array}$ & $\begin{array}{c}0 \\
0.0 \%\end{array}$ & 4.79 \\
\hline $\begin{array}{l}\text { Lack of state-of-the-art } \\
\text { training facilities. }\end{array}$ & $\begin{array}{c}303 \\
75.8 \% \\
\end{array}$ & $\begin{array}{c}81 \\
20.3 \% \\
\end{array}$ & $\begin{array}{c}6 \\
1.5 \%\end{array}$ & $\begin{array}{c}4 \\
1.0 \%\end{array}$ & $\begin{array}{c}6 \\
1.5 \%\end{array}$ & 4.68 \\
\hline $\begin{array}{l}\text { Mismanagement of available } \\
\text { resources. }\end{array}$ & $\begin{array}{c}271 \\
67.8 \%\end{array}$ & $\begin{array}{c}121 \\
30.3 \%\end{array}$ & $\begin{array}{c}5 \\
1.3 \%\end{array}$ & $\begin{array}{c}3 \\
0.8 \%\end{array}$ & $\begin{array}{c}0 \\
0.0 \%\end{array}$ & 4.65 \\
\hline $\begin{array}{l}\text { Unprofessional } \\
\text { administration. }\end{array}$ & $\begin{array}{c}260 \\
65.0 \%\end{array}$ & $\begin{array}{c}132 \\
33.0 \%\end{array}$ & $\begin{array}{c}5 \\
1.3 \%\end{array}$ & $\begin{array}{c}3 \\
0.8 \%\end{array}$ & $\begin{array}{c}0 \\
0.0 \%\end{array}$ & 4.62 \\
\hline \multicolumn{6}{|c|}{ Grand mean } & 4.71 \\
\hline
\end{tabular}

Table 1: Descriptive Analysis on the Challenges of Using the 2009 National

Sports Policy to Promote Nigeria's Foreign Policy

Source: Field Survey, 2018

Table 1 reveals that all of the respondents agreed on the low awareness about the 2009 National Sports Policy. The high mean (4.73) signifies that the average response is a strong agreement that there is low awareness about the 2009 National Sports Policy. Also, 400(100\%) of the respondents agreed that there is disconnection between the Ministry of Youth and Sports, the Ministry of Foreign Policy and sports and foreign policy research institutions. The high mean (4.81) 
also denotes that the average response is a strong agreement that there is a disconnect between the Ministry of Youth and Sports, the Ministry of Foreign Policy and sports and foreign policy research institutions.

The notion that since 2009, successive Nigerian governments have not adequately employed sports as a strategy for promoting the image of Nigeria in the international system was also agreed upon by all the respondents interviewed. With the fact also established earlier that since 2009, the performances of Nigerian sports teams in major competitions, especially in the Olympic Games and the FIFA World Cup (Senior Male Category) have not been impressive and below expectations, the conclusion can be drawn that successive Nigerian governments, since 2009, have not adequately employed sports as a strategy for promoting the image of Nigeria in the international system. The implication is that Nigeria is short-changing herself in the international system as many States strategically employ sports to project their desired image to other members of the international system and use this projected image to achieve desired foreign policy objectives.

The study also found that all the respondents agreed on the inadequacy of funding of sports in Nigeria. The high mean (4.79) also reveals that on the average, respondents strongly agreed on the inadequacy of funding of sports in Nigeria. From the results, 384(96.1\%) of the respondents agreed that there is the lack of state-of-the-art training facilities in Nigeria, 10(2.5\%) disagreed while 6(1.5) were undecided. The mean (4.68) also reveals the average response of a strong agreement that there is the lack of state-of-the-art training facilities in Nigeria. Using the 2016 Rio Olympic Games as a point of reference, it showed that inadequate funding was a major causal factor for Nigeria's dismal performances at the Olympics (Ebgujo, 2016; Ojo, 2016). While Britain spent about £274m on preparing the British contingent to the 2016 Rio Olympic Games (Herbert, 2016), only about $€ 1 \mathrm{~m}$ was budgeted for preparations for Nigerian athletes in the 2016 Appropriation Act. Thus, while Britain carted away 67 medals, 27 of which are gold to place second next to the United States of America on the medals' table, Nigeria could only manage to secure a single bronze medal in the football competition at the Olympics. Even the bronze medal was simply as a result of the resilience of the Football Team as they were largely abandoned by the Nigerian government at their training camp in the United States and they had to rely on the philanthropy of strangers to get themselves transported from the United States to Brazil to participate in the event! (Aluko, Nwogwugwu \& Adenuga, 2018).

The Table also shows that 392(98\%) of the respondents agreed that the mismanagement of available resources is a challenge, while $8(2 \%)$ disagreed. The mean (4.65) also shows that the average respondent strongly agreed that the mismanagement of available resources is a challenge in the sports sector of the country. The Table also shows that $392(98 \%)$ of the respondents agreed that the unprofessional administration in the sports sector constitute a challenge while $8(2 \%)$ of the respondents disagreed with a high mean of 4.62 showing that on the average, the respondents strongly agreed that the unprofessional administration in the sports sector constitute a challenge.

\section{Conclusion}

Nigeria's dismal performances in the Olympic Games and the FIFA World Cup Finals since 2009 have not provided the needed image laundry to ensure the articulation of a better image for Nigeria in the international community. This is a great pointer to the fact that the 2009 National Sports Policy has not been implemented, especially when viewed against the backdrop of the fact that critical stakeholders are not aware of the Policy.

\section{Recommendations}

The study recommends the urgent implementation of the 2009 National Sports Policy to ensure the utilisation of sports to promote the foreign policy objective of articulating a better image for Nigeria in the international community. To overcome the challenges of low awareness of the Policy and disconnect between the relevant Ministries and Research Institutes, a periodic joint monitoring of the implementation of the Policy by relevant stakeholders is advocated.

In the same vein, the Fourth Estate of the Realm, that is, the Press, must be made an active partner in sensitizing the general public, especially sports and foreign policy analysts, on the ideals contained in the new national sports policy as it has been identified that the very low level of awareness about the 2009 National Sports is a major contributory factor to its perceived ineffectiveness.

The Nigerian government, at all its levels, should also exhibit the will and readiness to make the Policy succeed by ensuring the provision of funds and other resources needed for the proper implementation of the Policy.

\section{References}

i. Ade-Ibijola, A. O. (2013). Overview of national interest, continuities and flaws in Nigeria foreign policy. International Journal of Academic Research in Business and Social Sciences, 3 (1), 565-572.

ii. Adenuga, G. A. \& A. K. Hassan (2011).The new partnership for Africa's development (NEPAD) and the quest for a new world order: problems and prospects. Religions' Educator, 14 (2), 107-114.

iii. Adesina, I. (2016, August 7). From Helsinki to Rio: Nigeria's Olympic journey. The Punch Newspaper.

iv. Aibueke, S. O. \& Ogbouma, S. (2013). Extent of implementation of the 2009 National Sports Policy of Nigeria: Implications for sports science, exercise science and sport medicine. Academic Research International, 4(2), 541549.

v. Aiyejina, T. (2016, July 24). From world's no. 5 to 70: Nigerian football under Pinnick. The Punch Newspaper.

vi. Ajayi, L., Njoaguani, T., Olorunyomi, B. \& Folarin, S. (2015). Nigeria's foreign policy and codification of national interest: A prescriptive analysis. Covenant University Journal of Politics and International Affairs, 3 (2), 68-81. 
vii. Ajom, J. (2017, August 23). Nigeria Sport: Falling standards, result of leadership vacuum. The Vanguard Newspaper.

viii. Akinboye, S. O. \& Basiru, A. S. (2014). Foreign policy analysis: conceptual and theoretical $\quad$ logic. Allen: Wits Publishing Ltd.

ix. Akinola, D. (2014, July 14). Super Eagles: the coach we do not need. The Vanguard Newspaper.

x. Aluko, J., Nwogwugwu, N. \& Adenuga, G. A. (2018). Sports as instrument for promoting Nigeria's $\quad$ foreign policy. The International Journal of Humanities \& Social Studies, 6(12), 54-64.

xi. Ameh, C. G. (2017, December 5). 2018 world cup: Nigerian government budgets N3bn for Super Eagles. The Daily Post.

xii. Ashaver, T. B. (2014). Continuities and discontinuities in Nigeria's foreign policy. International Journal of Development and Sustainability, 3 (2), 286-305.

xiii. Chidozie, F., Ibietan, J., \& Ujara, E. (2014). Foreign policy, international image and national transformation: A historical perspective. International Journal of Innovative Social Sciences \&Humanities Research, 2 (4), 49-58.

xiv. Cohen, H.J. (2015). The mind of the African strongman: Conversations with dictators, statesmen and father figures. Washington: New Academia Publishing.

xv. Daniel, I. U. (2014). Foreign policy and national interest: a case study of Nigeria-Cameroon border dispute. World Journal of Management and Behavioural Studies. 2 (1), 6-11.

xvi. Deos, A. (2014). Sport and relational public diplomacy: the case of New Zealand and Rugby World Cup 2011.Sport in Society, 17(9), 1170-1186.

xvii. Dumo, E. (2016, August 23) Messy expose into Nigeria's annual N4.6bn sports budget. The Punch Newspaper.

xviii. Grix, J. (2014). The attraction of sport mega-events to states of all political hues. In Hofmeister, W. (ed.). More than a game: sports, society and politics. Singapore: Konrad-Adenauer-Stiftung Ltd. P. 17- 22.

xix. Jeroh, E. J. (2012). Grassroots sports: conveyor belt for sports development in Nigeria. AFRREV IJAH, 1 (1), 265276.

xx. Lamido, S. (2012). Challenges of foreign policy making and implementation in Nigeria: an insider's perspective. A lecture presented at a conference organised by the Society for International Relations Awareness (SIRA) in collaboration with Friedrich Elbert Stiftung (FES) Nigeria at Protea Hotel, Asokoro, Abuja, Nigeria. Oct. 31 st.

xxi. Lawal, E. E. \& Aluko, O. I. (2016). Nigerian foreign policy: A fourth republic diplomatic escapade. Journal of Siberian Federal University Humanities and Social Science, 4 (9), 708-721.

xxii. Marleku, M. A. (2013). National interest and foreign policy: the case of Kosovo. Mediterranean Journal of Social Sciences, 4 (3), 415-419.

xxiii. Nauright, J. (2013). Selling nations to the world through sports: mega events and nation branding as global diplomacy. PD Magazine. P. 22-27.

xxiv. Ndlovu, S. M. (2010). Sports as cultural diplomacy: the 2010 FIFA world cup in South Africa's foreign policy. Soccer \& Society. 11 (1-2), 144-153.

xxv. Ngobua, D. (2016, August 6). Team Nigeria hunting for medals at Rio Olympics. The Daily Trust Newspaper.

xxvi. Nwankwo, G. O. \& Ekechukwu, R. O. (2017). Inadequate funding and substandard facilities as determinants of risks associated with football leagues in South-South geo-political zone of Nigeria: Implication $\quad$ for $\quad$ sports counselling. European Journal of Research and Reflection in Educational Sciences, 5 (1), 1-6.

xxvii. Okediji, H. (2015). The relevance of sports to the development of education in Nigeria, 1904 till date. Historical Research, 5 (3), 188-196.

xxviii. Okpara, C. (2018, May 7). Super Eagles' world cup fund committee targets N3billion. The Guardian Newspaper.

xxix. Pham, J. P. (2008). What is in the national interest? Hans Morgenthau's realist vision and America's foreign policy. American Foreign Policy Interests, 30, 256-265.

xxx. Sanubi, F. A. (2012). Assessing Nigeria's African-centred foreign policy against an inside-out paradigm; a proposal for an alternative foreign policy approach. Africana, 6 (1), 279-289.

xxxi. Shaagee, O. (2016, September 10). Dark cloud over team Nigeria's Olympic medals prospect. The Daily Trust Newspaper.

xxxii. Wogu, I. A. P., Sholarin, M. A. \& Chidozie, F. C. (2015). A critical evaluation of Nigeria's foreign policy at 53. Research on Humanities and Social Sciences, 5 (2), 137-147.

xxxiii. Yazid, L. I. (2014). Sports development; the Nigerian way: a review. International Journal of Physical Education, Sports and Health, 1 (4), 20-24. 